\title{
Chest Press
}

National Cancer Institute

\section{Source}

National Cancer Institute. Chest Press. NCI Thesaurus. Code C122032.

An exercise performed by using the arms to push a weighted bar or lever away from the chest while seated or reclined. 